\title{
THE HISTORY OF LGBTQ DISCOURSES IN INDONESIA
}

\author{
Perdian Tumanan ${ }^{1}$
}

There is prevalent perception that the past colonialization and the expansion of Christianity have deeply affected the sexual regulations and norms in the former colonized countries. This perspective unavoidably affects how Christians today see the recent debate on the Lesbian, Gay, Bisexual, Transgender, and Queer (LGBTQ) issue. The most prevailing perspective embraced by many conservative Christian leaders in the Global South today is that there is a political agenda from western countries by importing their liberal opinion on sexuality as a socially-chosen construct and not a naturally-given condition. For them, this is a new kind of colonialism. By discussing the specific case of Indonesia, the author argues that this is not always the case. By tracing back to the history of LGBTQ discourses in Indonesia, he attempts to show that colonization brought no impact on the recent LGBTQ debates. The discourses began to thrive in the last twenty years, mainly due to the internal political dynamics of Indonesia and the rise of Islamic populism after the 1998 reformation.

Keywords: LGBTQ, history, colonialism, Christianity, Indonesia

There are scholars and others who opine that the past colonialization by western countries and the expansion of Christianity have deeply affected the sexual regulations and norms in the former colonized countries. For instance, Merry Wiesner-Hanks, a historian from the University of Wisconsin-Milwaukee who researched the issue tracing it from 1500 to $1700 \mathrm{CE}$, concludes that the spread of Christianity beyond Europe during this period had brought significant impact on the pattern of sexuality in the former colonized countries (Wiesner-Hanks, 2010, p. 1). This perspective unavoidably affects how people see the recent debate about the Lesbian, Bisexual, Gay, Transgender, and Queer (LBGTQ). Albert B. Collver III, a

\footnotetext{
${ }^{1}$ Perdian Tumanan is a tenured lecturer in ethics, peacebuilding, and religion at Petra Christian University in Surabaya, Indonesia. Currently, he is pursuing doctoral studies in systematic theology and Christian ethics at Villanova University, PA, USA. Correspondence regarding this article must be directed to: perdian@petra.ac.id
} 
Lutheran theologian, makes this clear through a quotation from theological document of Lutheran World Federation: "The failure of the Church and Christians to accept homosexual love given in the framework of faithful and conjugal relationships reverts into a condemnation of homosexuality that is a reenactment of exclusionary categories inherited from a colonial and patriarchal past"(2016, p. 34). Max Perry Mueller, a religious scholar, also captures the same understanding from African Christian leaders:

Yet as "progressive" Christians in the so-called West label the church in the Global South —and their backers in the global church headquarters of Canterbury and Salt Lake-"un-Christian," there emerge not only shadows of early twentieth-century fights over Christian fundamentals, but also the specter of seventeenth-, eighteenth-, and nineteenthcentury colonialism. Some African church leaders who refuse to accept gay rights have described the assumption that they'd fall in line with American and European evolving understandings of sexuality as being akin to a colonial-era decree to "civilize" the benighted darker races. (Mueller, 2016)

This is a perspective embraced by many conservative Christian leaders in the Global South today and attribute it to a political agenda of the western countries by importing their liberal opinion on sexuality as a socially-chosen construct and not a naturally-given condition. For them, this is a new kind of colonialism (Kalende, 2014).

By discussing the specific case of Indonesia, I argue that this is not always the case. By tracing back to the history of LGBTQ discourse in Indonesia, I will attempt to show that colonialization brought no impact on the recent LGBTQ debates. ${ }^{2}$ The discourse began to thrive in the last 20 years, mainly due to Indonesian internal political dynamics and the rise of Islamic populism after the 1998 reformation. Most of the resources that discuss sexuality in Indonesia are around the issues of womanhood and feminism. The discourses on LGBTQ just began thriving recently, especially after the 1998 "reformation" movement that overthrew Suharto's thirty-two years of the "new order" regime. I will also examine several of its historical causes. This paper consists of two parts. In the first part, I will discuss the

\footnotetext{
${ }^{2}$ Merry Wiesner-Hanks, in her very short section about the impact of the Dutch colonization on its colonies' sexual regulations, does not talk much about Indonesia. She only explains about two specific areas, Batavia (now Jakarta) and a now-Christian-majority island, Moluccas. Moreover, the issue is not on LGBTQ but rather on marriage (Wiesner, 2010, pp. 245-246).
} 
LGBTQ discourse before the reformation and in the second, I will focus on its development after the reformation.

\section{Before the Reformation}

There are at least three main reasons why the discourses on LGBTQ began flourishing only recently. Firstly, there is a problem with what it means to have a country called Indonesia. What is known as Indonesia today was once hundreds of small independent kingdoms. Indonesia is a later political vision and imagination that emerged after those kingdoms suffered from colonialization (Boellstorff, 2005). So, Indonesia is not a socio-political reality that had existed from the outset.

Long before the colonial era, there existed indigenous traditions based on local religions that were supportive of sexual pluralism — such as transvestite Bissu community (South Sulawesi), or the $W$ arok tradition in Ponorogo (East Java). There is a disagreement whether these traditions could be used to support the major tendency of western developmentalists to assume them as the origin of LGBTQ people in Indonesia (Boellstorff, 2005). In Boellstorff's words, "Gay and lesbi Indonesians have received little academic attention not only because they do not fit within an ethnolocalized spatial scale, but because no discourse appears to correlate with their existence" (2005, p. 193).

Secondly, the overriding sexuality or gender issues, especially in the period of post-colonial era until reformation (1945-1998) were around feminism and women's oppression. The reason for the oppression was not necessarily a patriarchal culture that might have permeated in most of the local Indonesian cultures. In fact, there are major tendencies to non-patriarchy in the indigenous cultures of Indonesian archipelago, such as matriarchal familial system in Minangkabau, West Sumatera (Nanda, 2019). In Tana Toraja (South Sulawesi), both sexes (male and female) have the same right for inheritance. Both sexes are considered valuable. Roxana Waterson (2009) makes an important conclusion about this phenomenon:

What seems clear is that in many South-East Asian societies, men and women are thought of as fundamentally similar, rather than intrinsically and irremediably different, types of persons, and the differences between them are not posited as based in their essential 'natures' as gendered beings. If there are roles that women rarely achieve in many Indonesian societies, it is not because these are prohibited to them; 
actors may attribute the differences to chance, or to an individual's possession or lack of spiritual qualities (without particular reference to gender), even if from the outsider's point of view there may appear to be structural factors that in practice hamper women from assuming these roles. (p. 226)

Significant changes in gender issues came about mainly because of two major political upheavals that brought about a horrible impact on the women's movement. These events also marked the beginning of two political eras in Indonesia, the new order regime (1965) and the reformation era (1998).

In 1965, there was a massive massacre of those who were involved with Indonesian Communist Party (PKI). This massacre directly demolished PKI's women's organization, Gerwani (Indonesian Women Movement), the only women's organization at that time that worked for equality with men in terms of "equal labor rights for women and equal responsibilities in the struggle for 'full national independence' and socialism"(Wieringa, 2002, pp. 139-140). In 1998 , in his last attempt to maintain his presidency amidst massive student protests all over Indonesia, Suharto ordered raping of Chinese women and girls. This horrible event, which is well-known as "the tragedy of May 1998," eventually led to the formation of the National Commission on Violence against Women (Komnas Perempuan) on October 15"th 1998 ("Peristiwa Mei 1998," n.d.).

Thirdly, the systemic persecution and discrimination by the government of LGBTQ people occurred after the reformation era began in 1998. There were no significant threat and systematic persecution of LGBTQ people carried out either by the colonials or by the independent Indonesian governments from the pre-colonial era (before the $16^{\text {th }}$ century) up to the reformation era. Sharyn Graham Davies, an anthropologist from Auckland University of Technology, observe that "the Dutch and Japanese occupation left homosexuality and transgenderism untouched by law" (Davies, 2018, p. 326). Even though there was persecution of LGBTQ people by the Dutch special moral police called zedenpolitie between December 1938 and May 1939, it was temporary and mainly targeted Europeans and high officials within the government, not indigenous Indonesians (Putri, n.d.). The same-sex practice and relations were never prohibited by the Dutch civil law. That is why Boellstorff (2005) states that during the three-hundred years of Dutch colonialization, there was no specific attention that addressed same-sex relation (such as sodomy) in their civil law. 
Additional evidence comes from the fact that no discriminatory actions had been taken against the local LGBTQ Bissu community, even in Suharto's violent regime (Davies, 2018). The horrendous persecution that was experienced by Bissu community in 1960s through Operasi Tobat (Operation Repent) was executed not by the government, but by the militant Islamic guerrillas called Darul Islam/Indonesian Islamic Army (DI/TII) that rebelled against the government (Boellstorff, 2005).

It is also important to notice that in the late 1970s and early 1980s, people began to use the term "gay" and "lesbian" publicly, following the wave of gay and lesbian rights movements in the West (Davies, 2018). Several organizations were also formed to advocate gay rights, such as Lambda Indonesia and GAYa NUSANTARA. These organizations could even access the government sexual health funds amid the heavy concerns about HIV/ AIDS in the 1980s (Davies, 2018).

\section{After the Reformation}

The reformation era that was optimistically considered by many as one that would lead Indonesia to a better democracy, was, on the contrary, more oppressive and discriminatory regarding sexuality (Platt, Davies, \& Bennett, 2018). Initially, there was a high expectation, among other hopes as well, that the new government would legitimize the existence of the LGBTQ people. Davies writes that in 1999 she heard a speech of the mayor of Sengkang, a Bugis major district in South Sulawesi, where he was affirming that waria (transvestite) was an important part of Bugis community. He even ended his speech by saying, "Long live waria!” (Davies, 2018, p. 327). Sadly, it was a misplaced hope, and the reverse was the outcome.

There are two main reasons behind this anomaly: the rise of Islamic fundamentalism, and the decentralization of the political system. It is important to point out that during Sukarno (1945-1966) and Suharto's era (1966-1998), the Muslim fundamentalists were politically marginalized and existentially oppressed. The freedom of speech and political expression as two of the reformation mandates made them brave enough to come out from their hiding. They engaged in ideological campaign in the name of free speech. They were not even afraid to show their true identities and activities in public space-something that was dangerous in Suharto's era. Eventually, rather than being an era for true democracy, the reformation became an open 
arena for power contestation. "Reformasi thus created a space for increasing Islamization" (Platt et al., 2018, p. 4).

The first president in the reformation era was Abdurahman Wahid. Before he became the president, he was the Chairman of Nabdlatul Ulama, the moderate and traditionalist Islam organization with more than forty million members. It was the biggest religion-based organization in the country. He beat the strongest candidate, Megawati Sukarnoputri, in the election held by the People's Consultative Assembly (MPR RI). Megawati was the daughter of Sukarno and the Chairwoman of Indonesian Democratic Party of Struggle (PDIP), the winner of the first election after the reformation. As her father, she represented the secular nationalist group. The victory of Abdurahman Wahid, who was supported by Islamic political parties, was celebrated as the victory of Islam over the secular nationalist party that was already occupying the country for 53 years.

The economic crisis during Sukarno's era, the corrupt government of Suharto (and his family), and the horrendous raping and killing before he was deposed, were creating another narrative among Muslims after the reformation. It was a new narrative of morality (Platt et al., 2018). For them, the problem of this nation was its failed morality. The secular nationalist governments failed because they were not addressing the morality problem as a serious matter. This narrative successfully brought Abdurahman Wahid to the presidency. Even though he was well-recognized as a leading figure of human rights, he used this Islamic morality narrative to gain support. Platt et al. (2018) conclude: "Wahid promoted religious morality as a key currency in establishing his political legitimacy. He explicitly proposed Islam as a path away from moral corruption. Indonesian Muslims were encouraged to break with the moral laxity of the past" (p. 4).

This morality narrative was effectively applied in another of the reformation outcomes, decentralization policy, also known as regional autonomy. Decentralization policy was the reaction to the Java-minded, centralistic, and militarized government system operated by Suharto. The end goal of this policy was to create a development system that was in line with the local context and cultural wisdom of every region. However, again, the outcome was the contradictory. Rather than applying local cultural wisdoms, several provinces and districts started to apply shari'a principles 
into their local government rules. Buehler (2016) states that there were 443 regulations connected with Sharia law that was adopted from 1998 to 2013. This development directly affected the LGBTQ communities as Platt et al. (2018) observe: "While it was hoped that decentralization would enable local governments to operate in ways sensitive to local communities, in reality, many local governments ratified homophobic and transphobic laws" (p. 327).

\section{Conclusion}

From this historical explanation, it is important to highlight that the common understanding that the Western colonialization (with its 'Christianization agenda') brought significant change to sexuality discourse in the former colonized countries does not apply to the Indonesian context. Sexuality discourses in Indonesia mainly come from its internal political dynamics. The fact that before the reformation there was no systematic oppression and discrimination toward the LGBTQ communities proves that generally Indonesians have been welcoming towards the LGBTQ people. Bissu community and Warok tradition, for example, could live in peace among Bugis and Ponorogo's Muslim majority for more than three centuries.

Unfortunately, most of the LGBTQ discourses in Indonesian churches do not give enough attention to the power and political dynamics in Indonesia's own historical context. Most of them are more motivated by the recent discourses that have developed in the western world. Gerrit Singgih, a prominent Indonesian biblical scholar, has attempted to address the LGBTQ polemic in Indonesia by proposing a hermeneutical method, which he calls "sola scriptura plus." For him, rather than discerning the LGBTQ polemic only from the biblical perspective, it is also important to examine the problem from recent discourses that contribute to the polemic, discourses such as science vs faith debate and cultural and human rights issues. Even in his book, he never considers the internal historical power and political dynamics (Singgih, 2019). The current LGBTQ discourses, a least in the Indonesian context, cannot be analyzed and understood apart from the historical and political context of the country, besides other vantage points of hermeneutics. I suspect that the same hypothesis applies to other cultures as well. 


\section{References}

Boellstorff, T. (2005). The Gay Archipelago: Sexuality and nation in Indonesia. Retrieved from http://ebookcentral.proquest.com/lib/ambs-ebooks/detail.action?docID=1565231

Buehler, M. (2016). The politics of Shari'a Law: Islamist activists and the state in democratizing Indonesia. Cambridge: Cambridge University Press.

Collver III, A. B. (2016). Colonialism in the global south: The imperialism of western sexual ethics. Journal of Lutheran Mission, 3(1), 34-39.

Davies, S. G. (2018). Gender and sexual plurality in Indonesia: Past and present. In R. W. Hefner (Ed.), Routledge handbook of contemporary Indonesia. New York: Routledge.

Kalende, V. (2014, April 30). Africa: Homophobia is a legacy of colonialism. The Guardian. Retrieved from https://www.theguardian.com/world/2014/apr/30/africahomophobia-legacy-colonialism

Mueller, M. P. (2016, February 23). Mormons, Anglicans, and why global churches struggle over LGBT rights. Religion \& Politics. Retrieved from https://religionandpolitics. org/2016/02/23/mormons-anglicans-and-why-global-churches-struggle-over-lgbtrights/

Nanda, S. (2019). Love and marriage: Cultural diversity in a changing world. Long Grove, IL: Waveland Press.

Peristiwa Mei 1998. (n.d.). Retrieved from https://www.komnasperempuan.go.id/sejarah

Platt, M., Davies, S. G., \& Bennett, L. R. (2018). Contestations of gender, sexuality and morality in contemporary Indonesia. Asian Studies Review, 42(1), 1-15. https:/ /doi.org /10.1080/10357823.2017.1409698

Putri, R. H. (n.d.). Razia homoseksual zaman kolonial. Retrieved from https://historia.id/ politik/articles/razia-homoseksual-zaman-kolonial-PdjAZ

Singgih, E. G. (2019). Menafsir LGBT dengan Alkitab: Tanggapan terhadap pernyataan pastoral Persekutuan Gereja-Gereja di Indonesia (PGI) mengenai LGBT. Jakarta: Sekolah Tinggi Filsafat dan Teologi Jakarta.

Waterson, R. (2009). Paths and rivers: Sa'dan Toraja society in transformation. Leiden: KITLV Press.

Wieringa, S. (2002). Sexual politics in Indonesia. New York: Palgrave Mcmillan.

Wiesner-Hanks, M. (2010). Christianity and sexuality in the early modern world: Regulating desire, reforming practice (2nd ed.). London: Routledge. 